\title{
EDITORIAL
}

\section{WHY HEALTH WORKFORCE MATTERS: REFLECTIONS FROM CURRENT PANDEMIC AND PAST PROGRAMS EXPERIENCES}

\author{
Mengapa Tenaga Kesehatan Penting: \\ Refleksi dari Situasi Pandemi dan Pengalaman Program Terdahulu \\ Nur Atika, SKM., MPH. \\ Section Editor \\ Indonesian Journal of Health Administration \\ Email: atika217@gmail.com
}

A well-functioning health system depends largely on the quantity and capacity of health human resources who have responsibilities for organizing and implementing health services. A proper arrangement of health workers in terms of numbers, competencies, and diversity is necessary for responding to healthcare needs and achieving health program goals. The need for adequate and skilled health professionals has become even more urgent in the time of the current pandemic situation to ensure the resiliency of health systems. In responding to the COVID-19 pandemic, especially in Indonesia, attention is intensively paid to the aspect of facilities such as hospitals, as well as testing and protective equipment. However, we should not forget that the readiness of human resources including clinicians, nurses, laboratory staff, ambulance drivers, and so on are also of paramount importance.

In this edition of the Indonesian Journal of Health Administration, Firmansyah, Rahmanto and Setyawan (2020) found that the ratio of health workers for specifically handling the COVID-19 patients was not ideal compared to some countries. The ratio of health workers for doctor and nurse were 0.4 and 2.1, respectively, meaning that there were only 4 doctors for 10,000 people and 21 nurses serving for 10,000 people Firmansyah, Rahmanto and Setyawan (2020). As the frontline actors in the battle of the current pandemic, it is reasonable for the authors to suggest the policymakers to put more attention on the aspect of human resources in terms of the quantity as well as the capacity.

In this edition, we also invite all readers to reflect on the district health management in Low-and Middle-Income Countries (LMICs) from a commentary article written by Omar (2020) which emphasized on the importance of a shared vision of district strengthening, capacity building for individuals who are involved in the district management team, as well as the improvement of the systems. Another research by Hiola and Badjuka (2020) scrutinized factors which influenced village Midwife performance in relation to their work for reducing maternal and infant mortality rate. Midwife as one of health human resources has an important role in increasing the quality of maternal services to reduce maternal mortality rate (MMR) and infant mortality rate (IMR). Their study revealed that work period, rewards, and motivation were among the influencing factors on their 
performance. Therefore, providing training and increasing rewards proportionally are some of their recommendations to boost their motivation and performance (Hiola and Badjuka, 2020).

Highlighting the issue of motivation and performance, this edition also presented a paper that indicated the association of nurses' performance and nurses' work motivation as well as the role of leadership of the Head of inpatient room at the Indonesian Red Cross Hospital (Hartono et al., 2020). Better nursing performance and an increase in nurse' work motivation was influenced by the leadership of the managers. Hence, enhancing leadership skills through regular training is one of strategies which was mentioned by the authors (Hartono et al., 2020).

Turning to the primary health care (PHC) setting, we invite readers to reflect on the experience of a tuberculosis prevention program team in Surabaya. A study showed that team effectiveness in implementing the TB prevention program in PHC in Surabaya was affected by the dimension of task variety, task identity, and task significance (Lestyoningrum et al., 2020). PHCs need to utilize technology in upgrading the span of control, centralization, and understanding task characteristics to improve team performance. Another study by Arifah et al. (2020) investigated the determinants of access to Adolescent-Friendly Health Service. This study also suggested the use of technology, particularly electronic media, in the dissemination of information by health professionals to adolescents so that they can be well-informed about the program. Their study found that the proportion of adolescents who accessed the program was still low, and the number of adolescents who accessed the program via health professionals were lower than through peer educators. Insufficient knowledge about the program was identified as the reason for low access (Arifah et al., 2020). Thus, massive socialization using digital technology by health professionals or those who manage the program might be a suitable approach to escalate access.

The discussion on health workforce is not only limited to its recruitment, capacity building, distribution, and performance, but it is also crucial to consider the retention aspect. A study conducted by Santi, Nandini, and Alfiansyah (2020) in this edition of our journal evaluated the effect of burnout syndrome on turnover intention in Surabaya Surgical Hospital. As turnover can cause loss to the organization and health workers are prone to experience burnout syndrome, the authors want to analyze its association using organization commitment as an intermediate variable. The study found that burnout syndrome can be a possible factor which caused turnover intention if organization commitment decreased; therefore, reducing burnout syndrome and improving organizational commitment through a better reward system are some plausible recommendations for hospital managers to minimize turnover intention (Santi, Nandini, and Alfiansyah, 2020).

Concerning the current outbreak, the risk of burnout syndrome is likely to be suffered by health workers who handle COVID-19 patients. An online survey involving 1,461 medical workers revealed moderate levels of burnout were experienced by the majority of respondents $(82 \%)$, which might subsequently also influence their well-being and performance (Nurbaiti, 2020). This is an alarming situation that urges us to be more vigilant and responsive to prevent any severe condition.

Finally, I enclosed this editorial greeting by a popular quote which stated: 


\section{DJAKI \\ IURNAL ADMINISTRASI
KESEHATAN INDONESIA

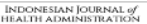

"the heart of every organization is its people". Investing best resources and efforts to provide and maintain qualified health human resources is a promising strategy to achieve health development goals. Because human resources for health are valuable assets, their existence, contribution, and issue will always matter.

\section{REFERENCES}

Arifah, I. et al. (2020) 'The Determinants of Access to Adolescent-Friendly Health Service: A Case Control Study', Jurnal Administrasi Kesehatan Indonesia, 8(2), pp. 164-174.

Hartono, B. et al. (2020) 'The Effect of Head's Leadership and Nurses' Job Motivation on Nursing Performance in The Hospital Inpatient Room', Jurnal Administrasi Kesehatan Indonesia, 8(2), pp. 175-187.

Hiola, T. T. and Badjuka, B. Y. M. (2020) 'The Analysis of Village Midwife Performance in Reducing Maternal and Infant Mortality Rate', Jurnal Administrasi Kesehatan Indonesia, 8(2), pp. 141-150.

Lestyoningrum, S. D. et al. (2020) 'The Effect of Organization's Structure and Task Characteristics on Team Effectiveness
Jurnal Administrasi Kesehatan Indonesia Volume 8 No 2 December 2020

Published by Universitas Airlangga doi: 10.20473/jaki.v8i2.2020.106-108

in Tuberculosis Prevention Program', Jurnal Administrasi Kesehatan Indonesia, 8(2), pp. 151-163.

Nurbaiti, A. (2020) 'COVID-19: Concerns Mount As Medical Workers Suffer Pandemic Burnout', The Jakarta Post, 5 September 2020, viewed 1 Oct 2020, https://www.thejakartapost.com/news/ 2020/09/05/covid-19-concerns-mountas-medical-workers-suffer-pandemicburnout-.html

Omar, M. A. (2020) 'Strengthening District Health Management in Low-Middle Income Countries: Reflections and Way Forward', Jurnal Administrasi Kesehatan Indonesia, 8(2), pp. 123140.

Firmansyah, M. I., Rahmanto, F. and Setyawan, D. (2020) 'The Preparedness of Medical Services in Handling COVID-19 Pandemic in Indonesia', Jurnal Administrasi Kesehatan Indonesia, 8(2), pp. 188201.

Santi, M. W., Nandini, N. and Alfiansyah, G. (2020) 'The Effect of Burnout Syndrome on Turnover Intention Using Organizational Commitment As An Intermediate Variable', Jurnal Administrasi Kesehatan Indonesia, 8(2), pp. 109-122 